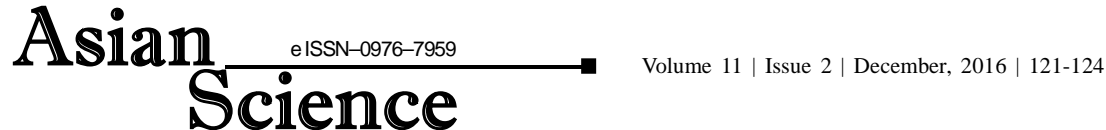

DOI : 10.15740/HAS/AS/11.2/121-124

Visit us | www.researchjournal.co.in

RESEARCH PAPER

\section{Consumer responsibility of low sugar, low calorie and fibre enriched Lal Peda}

\author{
B.C. ANDHARE*, D.C. RAI AND TANWEER ALAM ${ }^{1}$ \\ Banaras Hindu University, VARANASI (U.P.) INDIA
}

\begin{abstract}
Varanasi, the city of gallis and ghats is not only famous for its Banarasi saree and Banarasi paan, but also famous for the Lal Peda loaded with higher amount of sugar and loaded with Ghee, the Peda is shaped by hand and dusted with semolina and pistachios as a finishing touch. Lal Peda is a popular heat desiccated traditional dairy delicacy of eastern India specially Uttar Pradesh. It is prepared by blending of Khoa and sugar followed by heat desiccation until characteristic reddish brown colour appears. The Lal Peda is deficit in fibre so the developed Lal Peda was prepared with addition of oat. This product is manufactured since long time yet not glamorized as other Khoa based sweet products like Burfi, Peda etc. The main reason behind this is, these products centered into specific areas and have not proper focused by research scientists and extension workers. So the experiment was carried out on low calorie, low sugar and fibre enriched Lal Peda. The process for the manufacture of low calorie, low sugar and fibre enriched Lal Peda was standardized. Optimization of product stages and levels of addition of maltodextrin, sorbitol, oat, sugar and aspartame were used with help of sensory evaluation score. Hence, the formulation with buffalo milk with 3 per cent fat, 2 per cent maltodextrin, 0.50 per cent oat on the basis of milk and 20 per cent sugar and 0.10 aspartame on the basis of Khoa were considered to be the most appropriate formulation for preparation of low sugar, low calorie and fibre enriched Lal Peda. The proximate composition of developed Lal Peda contained 17.95 per cent moisture, 14.28 per cent fat, 16.93 per cent protein, 13.58 per cent lactose, 20.18 per cent sugar, 3.18 per cent ash and 4.18 per cent dietary fibre. The developed Lal Peda samples were tasted to 125 consumers selected randomly. The consumers were picked-up randomly under different age, sex and health groups. Among the consumers suffering from various diseases 93.5 per cent consumers rated the product liked extremely and liked very much.
\end{abstract}

Key Words : Low sugar, Low calorie, Fibre, Lal Peda, Consumer responsibilty

View point paper : Andhare, B.C., Rai, D. C. and Alam, Tanweer (2016). Consumer responsibility of low sugar, low calorie and fibre enriched Lal Peda. Asian Sci., 11 (2): 121-124, DOI : 10.15740/HAS/AS/11.2/121-124.

\footnotetext{
* Author for correspondence (Present Address)

B.C. Andhare, College of Agriculture, Badnapur, Jalna (M.S.) INDIA (Email: andharebcshree@gmail.com)

${ }^{1}$ Tanweer Alam, Indian Institute of Packaging, NEW DELHI, INDIA
} 